\title{
RANCANG BANGUN TUNGKU BIOMASSA HEMAT ENERGI DAN RAMAH LINGKUNGAN PADA TUNGKU TRADISIONAL MASYARAKAT BERBAHAN BAKAR KAYU
}

\author{
Abrar Ridwan \\ Universitas Muhammadiyah Riau \\ Email: ridwanabrar@yahoo.com
}

\begin{abstract}
ABSTRAK
Teknologi tungku pembakaran telah lama berkembang pesat dimasyarakat dan masih digunakan khususnya propinsi Riau yang kaya akan sumber daya biomassa. Telah dilakukan perancangan dan pembuatan tungku hemat energi dan ramah lingkungan dengan sistem downdraft-gasification, tungku berdimensi 1 x 1 x 1,2 m dengan tabung 13 lobang udara primer dan 21 lobang udara sekunder dengan tinggi $40 \mathrm{~cm}$ dan diameter $35 \mathrm{~cm}$. Pengujian dilakukan dengan 6 liter air yang mendidih pada menit ke18,73 pada temperatur $99{ }^{\circ} \mathrm{C}$ untuk tungku modifikasi dan temperatur air tertinggi $83,75{ }^{\circ} \mathrm{C}$ pada menit 45,83 untuk tungku tradisional masyarakat dengan menggunakan $3 \mathrm{~kg}$ kayu bakar, kecepatan aliran udara primer $0,59(\mathrm{~g} / \mathrm{s})$ dan 0,0034 (m3/s) udara sekunder . Efisiensi termal pada tungku modifikasi 14,7 \% dan efisiensi termal pada tungku tradisional masayarakat $4,2 \%$. Proses semi-gasification pada pembakaran memberi dampak berkurangnya asap hasil pembakaran dan isolator dengan serbuk gergaji memberi akumulasi panas yang bersifat adiabatis.
\end{abstract}

Kata kunci Tungku, efisiensi energi, downdraft-gasification, udara primer dan sekunder

\section{PENDAHULUAN}

Provinsi Riau merupakan daerah yang kaya akan sumber daya biomasa sebut saja kabupaten Indragiri Hilir yang merupakan kabupaten penghasil buah kelapa terbesar. Cangkang kelapa yang menjadi limbah rumah tangga sangat prospektif untuk menjadi bahan bakar tungku biomasa dengan nilai kalori $23012 \mathrm{kj} / \mathrm{kg}$. Kabupaten Kampar juga terkenal dengan luas areal hutan 8.598.757 Ha berpotensi untuk bahan bakar biomasa kayu dan kabupaten Rokan Hulu yang merupakan penghasil terbesar kelapa sawit di provinsi Riau yaitu 380.281 Ha. (Badan Pusat Statistik Provinsi Riau " Riau dalam angka 2010). Dengan banyaknya Bahan bakar biomassa yang ada di provinsi Riau, masyarakat Riau juga banyak yang menggunakan tungku tradisonal seperti UKM produksi tahu, rumah makan dan restoran Padang serta produk makanan lainnya yang merupakan aset terfavorit di Provinsi Riau. Selain itu masyarakat yang berada di daerah terisolir masih sulit untuk mendapatkan bahan bakar fosil dan gas LPG yang semakin hari semakin mahal sehingga harus memasak dengan bahan bakar biomasa (kayu, cangkang kelapa, ranting), dimana asap yang dihasilkan dari pembakaran dapat berdampak terhadap kesehatan dan emisi gas metana yang lebih berbahaya 21 kali lipat dibandingkan $\mathrm{CO}_{2}$. Melihat fenomena diatas perlu dilakukan alternatif tungku biomassa tradisional masyarakat yang hemat energi dan ramah lingkungan.

Disamping itu, penggunaan bahan bakar biomass pada dapur tradisional menimbulkan asap yang sangat banyak. Asap tersebut, bila terhirup dalam jumlah berlebih berpotensi menimbulkan gangguan fungsi pernafasan. Publikasi PBB menunjukkan bahwa tiap tahun lebih dari 1 juta orang di dunia yang meninggal karena infeksi akut pernafasan yang disebabkan karena menghirup udara berasap di dapur. Dengan demikian penting sekali mendesain satu jenis kompor biomass yang efisien dan ramah lingkungan. 

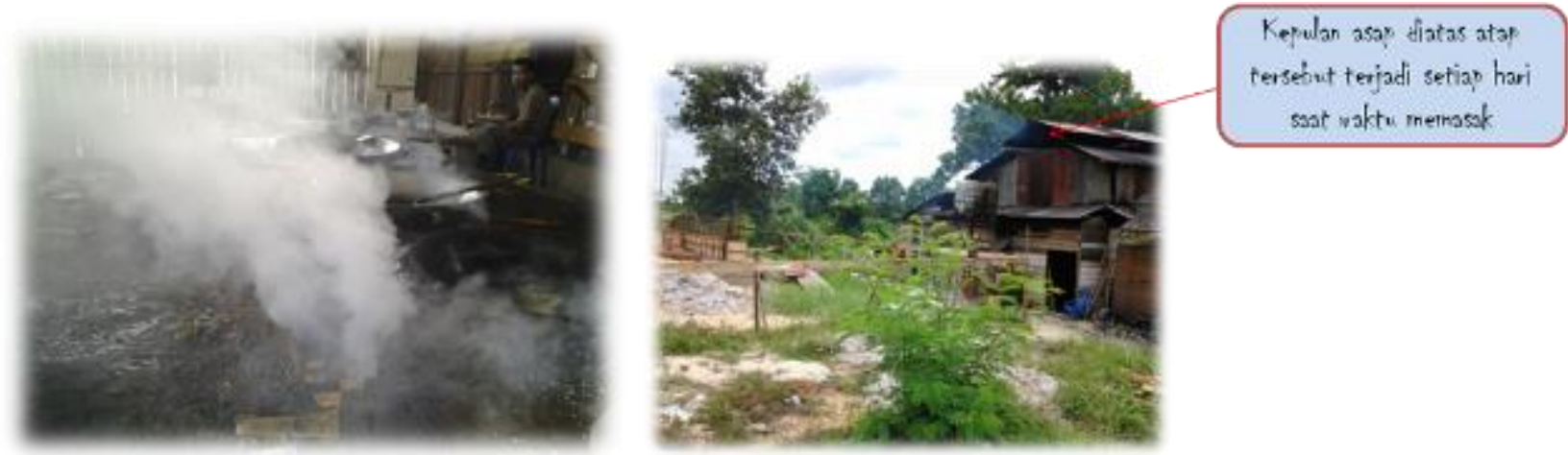

Gambar 1: Tipikal dapur tradisional yang ada di pedesaan di Indonesia.

Proses masak dengan bahan bakar kayu sangat efektif pada rumah makan yang ada di Provinsi Riau selain murah cita rasa masakan jauh lebih nikmat. Tungku biomasa tradisional yang akan diterapkan merupakan kompor berbahan bakar biomasa padat. (M.Nurhuda, 2009)

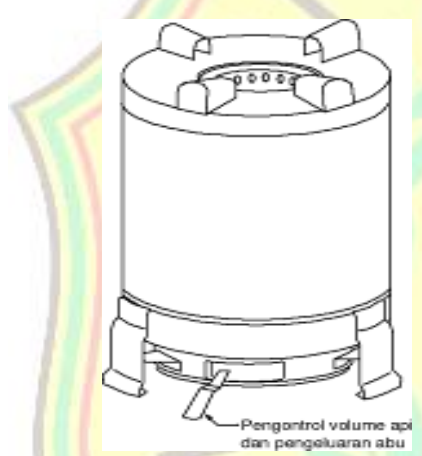

Gambar 2: Kompor biomass UB-03.

Biomasa terbakar oleh proses pirolisis dan gasifikasi yang menghasilkan asap. Secara kimia, asap pembakaran tersusun atas gas-gas diantaranya adalah $\mathrm{H}_{2}, \mathrm{CO}, \mathrm{CH}_{4}, \mathrm{CO}_{2}, \mathrm{SOx}$, NOx dan uap air. Sebagian gas-gas tersebut, yaitu hydrogen $\left(\mathrm{H}_{2}\right)$, karbonmonoksida (CO), dan metana $\left(\mathrm{CH}_{4}\right)$ adalah gas-gas yang dapat terbakar, sehingga dapat dimanfaatkan menjadi bahan bakar. Dengan demikian, untuk meningkatkan efisiensi penggunaan biomass sebagai bahan bakar, maka asap yang dihasilkan pada proses pengarangan harus dibakar lagi untuk kedua kali dan menghasilkan api yang mempunyai nyala yang lebih bersih.Ketika terjadi pembakaran kimia, ikatan-ikatan di dalam molekul-molekul dari reaktan-reaktan menjadi terputus, dan atom-atom dan elektronelektron tersusun ulang menjadi produk-produk. Di dalam reaksi pembakaran, elemen-elemen bahan bakar yang mudah terbakar mengalami oksidasi yang cepat sehingga menghasilkan pelepasan energi bersamaan dengan terbentuknya produk hasil pembakaran. Tiga elemen kimia utama yang mudah terbakar di dalam bahan bakar yang paling umum ditemukan adalah karbon, hidrogen, dan sulfur. Sulfur biasanya merupakan kontributor yang relatif tidak penting dalam pelepasan energi, tapi dapat menjadi signifikan karena permasalahan dengan polusi dan korosi yang disebabkannya. Pembakaran dituntaskan ketika semua karbon yang terkandung di dalam bahan bakar telah habis terbakar menjadi karbon dioksida, semua hidrogen telah habis terbakar menjadi air, dan semua sulfur telah habis terbakar menjadi sulfur dioksida, dan semua elemen-elemen yang mudah terbakar lainnya telah teroksidasi. Jika kondisi-kondisi seperti ini tidak terpenuhi, pembakaran menjadi tidak sempurna. Reaksireaksi pembakaran dapat dinyatakan melalui persamaan kimia:

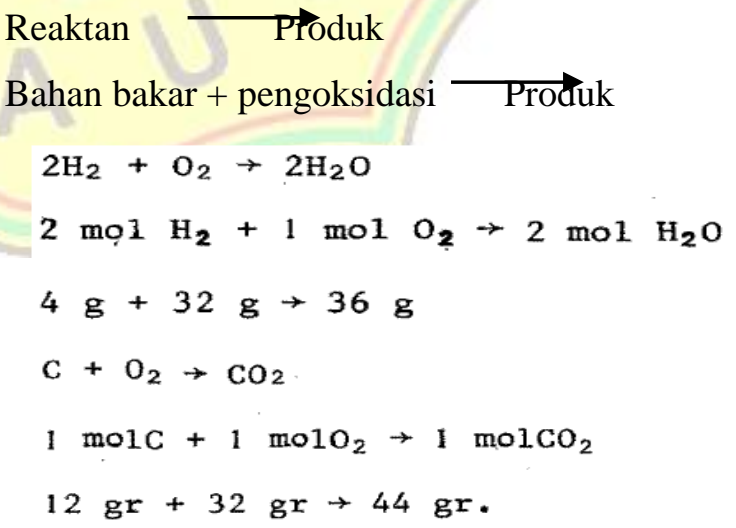

(Bryden, M., Still, D., Scott, P., Hoffa, G., Ogle, D., Bailis, R., and Goyer, K., 2005)

Rasio udara - bahan bakar merupakan dua parameter yang sering dipakai untuk 
memberikan kuantifikasi jumlah bahan bakar dan udara di dalam sebuah proses pembakaran. Rasio udara - bahan bakar singkatnya adalah rasio jumlah udara di dalam sebuah reaksi terhadap jumlah bahan bakar. Rasio ini dapat dituliskan dengan basis molar ( mol udara dibagi

$$
\begin{gathered}
\frac{\text { massa udara }}{\text { massa bahan bakar }}=\frac{\text { mol udara } x M_{\text {udara }}}{\text { mol bahan bakar } x M_{\text {baha }}} \\
=\frac{\text { mol udara }}{\text { mol bahan bakar }}\left(\frac{M_{\text {udara }}}{M_{\text {bahan bakar }}}\right) \\
\qquad A F=\overline{A F}\left(\frac{M_{\text {udara }}}{M_{\text {bahan bakar }}}\right)
\end{gathered}
$$

(Baldwin F., 2005)
Dimana $\overline{A F}$ adalah rasio udara-bahan bakar dengan basis molar dan $A F$ adalah rasio dengan basis massa. Jumlah minimum udara yang memberikan oksigen yang cukup untuk pembakaran sempurna terhadap semua karbon, hidrogen, dan sulfur yang terkandung di dalam bahan bakar disebut jumlah udara teoritis. Untuk pembakaran sempurna dengan jumlah udara teoritis, produk udara yang dihasilkan terdiri dari karbon dioksida, air, sulfur dioksida, nitrogen yang menyertai oksigen di dalam air, dan setiap nitrogen yang terkandung di dalam bahan bakar. Oksigen bebas tidak akan muncul sebagai salah satu produk pembakaran [6]. Rasio udara terhadap bahan bakar sangat dibutuhkan bertujuan untuk menentukan berapa luas atau lobang aliran udara yang masuk ke ruang pembakaran (udara primer) dan untuk membakar gas volatil (udara sekunder). Untuk menentukan efisiensi perpindahan panas agar kalor yang keluar hanya sedikit maka diperlukan isolator, dalam mendisain ketebalan isolator yang diinginkan hendaknya ditentukan dahulu berapa panjang jari-jari dari pusat ruang pembakaran, dalam hal ini isolator yang digunakan sekam padi karena nilai konduktivitas thermalnya yang rendah. Referensi illustrasi persamaan perpindahan panas resistansi pada tabung silindris ditampilkan pada gambar 3 .

Kekurangan cadangan bahan bakar fosil dan rusaknya atmosfer di bumi tidak bisa ditolerir sehingga perlu adanya inovasi teknologi yang mendukung keberlanjutan energi. Ruang lingkup teknik pembakaran pada tungku biomasa sangat menjanjikan dimana kegiatan masak-memasak dengan mol bahan bakar) atau dengan basis massa (massa udara dibagi dengan massa bahan bakar). Konversi di antara kedua nilai ini dilakukan dengan menggunakan berat molekuler dari udara, $M_{\text {udara }}$ dan bahan bakar $M_{\text {bahanbakar }}$ adalah kegiatan rutin manusia dan sebaliknya akan berdampak merugikan bagi makhluk hidup apabila benar-benar tidak diperhatikan aspek keamanan, kenyamanan dan efisiensi. Maka daripada itu perlu dilakukan perancangan dan pembuatan tungku biomassa tradisional yang heat energi dikarenakan proses pembakaran ulang gas yang mudah terbakardan isolasi ruang pembakaran dari udara lingkungan penelitian mengenai tungku biomasa tradisional yang hemat energi, ramah lingkungan dan mudah dalam penggunaan dan perawatannya. Agar dapat mengetahui tingkat performansi tungku perlu dihitung nilai efisiensi termal tungku.

$$
n=\frac{m_{w} * C\left(T_{b}-T_{i}\right)+m_{v} * R}{m_{f} * B} * 100 \%
$$

Dimana:

$$
\begin{array}{ll}
\eta & =\text { Efisiensi termal } \\
\mathrm{m}_{\mathrm{w}} & =\text { Berat awal air }(\mathrm{kg}) \\
\mathrm{m}_{\mathrm{f}} & =\text { Berat bahan bakar kayu }(\mathrm{kg}) \\
\mathrm{C} & =\text { Panas spesifik air }\left(\mathrm{Kj} / \mathrm{kg}{ }^{0} \mathrm{C}\right) \\
\mathrm{T}_{\mathrm{b}} & =\text { Temperatur titik didih air }\left({ }^{\circ} \mathrm{C}\right) \\
\mathrm{T}_{\mathrm{i}} & =\text { Temperatur awal air }\left({ }^{\circ} \mathrm{C}\right) \\
\mathrm{m}_{\mathrm{v}} & =\text { Berat air terevaporasi selama } \\
\mathrm{R} & =\text { Nilai pengujian }(\mathrm{kg}) \\
\mathrm{B} & \text { panas penguapan air pada } \\
\text { tekanan atmosfer } & \text { Nilai kalor bahan bakar kayu }(\mathrm{kj} / \mathrm{kg} \\
& \text { 0C) }
\end{array}
$$

(K.Krishna Prasad, 1981) 


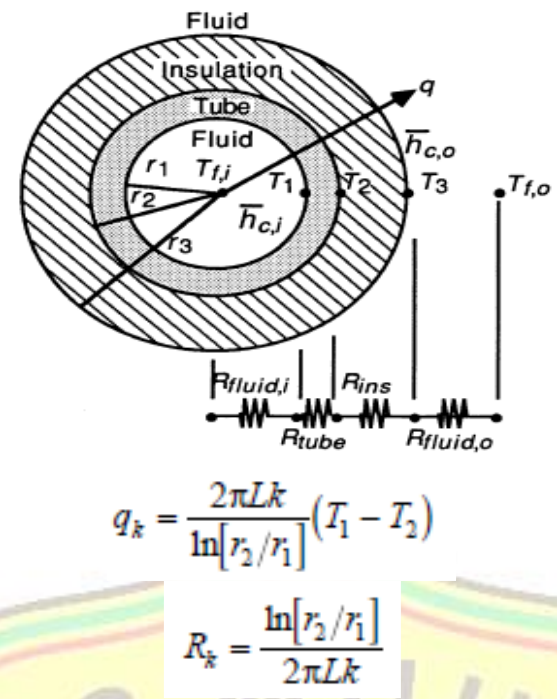

Gambar 3. Referensi illustrasi persamaan perpindahan panas resistansi pada tabung silindris (Michael J. Moran dan Howard N. Shapiro 2004, (2005)

\section{METODOLOGI PENELITIAN}

Alat yang digunakan dalam penelitian adalah Advantech DAQ 4718 sebagai konverter akuisisi data temperatur dengan sensor termokopel tipe $\mathrm{K}$ yang total panjangnya $20 \mathrm{~m}$. Sebagai penampilan data digunakan laptop tipe Asus. Timbangan dengan digit dua angka dibelakang koma untuk mengukur masing- masing kayu bakar yang akan digunakan. Bomb kalorimeter digunakan untuk men gukur nilai kalori bahan bakar, sedangkan mengukur laju aliran udara ke dalam ruang pembakaran digunakan hot wire - anemometer. Berikut adalah flow chart penelitian yang dilakukan.

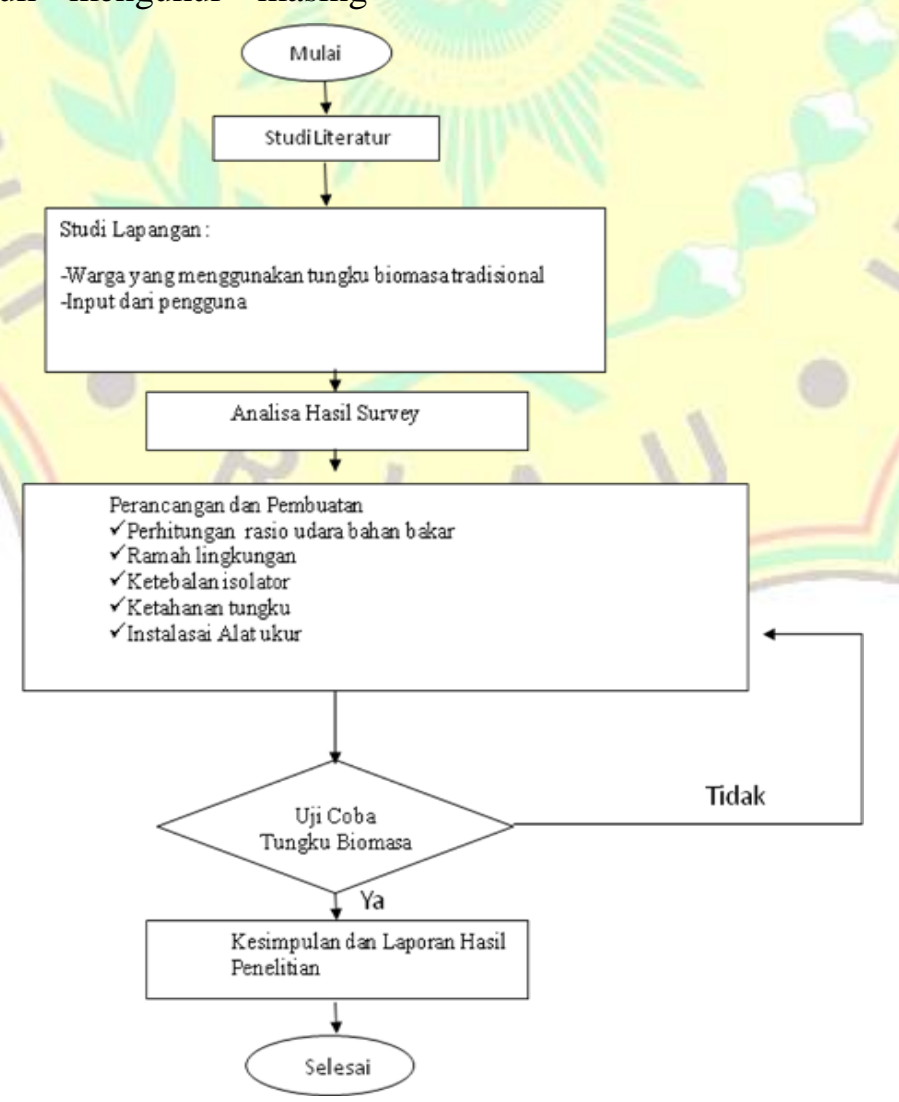

Gambar 3. Flowchart metode penelitian 


\section{HASIL DAN PEMBAHASAN}

Hasil perancangan yang telah dilakukan didapat beberapa tabel yang akan menjadi acuan untuk membuat tungku yang hemat energi dan ramah lingkungan. Konstanta dan nilai entalpi bahan bakar diuji dengan bomb calorimetry. Laju aliran massa tungku dapat dihitung dengan berat bahan bakar terhadap lama waktu pembakaran, sehingga di dapat hasil tabel dibawah ini.

Tabel 1. Keterangan nilai kalori, massa, dan waktu pembakaran

\begin{tabular}{|l|c|l|}
\hline \multicolumn{1}{|c|}{ Deskripsi } & $\begin{array}{c}\text { Nilai } \\
\text { Perhitungan }\end{array}$ & Keterangan \\
\hline Nilai Kalori Kayu Cemara $(\mathrm{Kj} / \mathrm{Kg})$ & 18.730 & Dengan moisture content $15 \%$ \\
\hline Berat Kayu Bakar $(\mathrm{Kg})$ & 3 & \\
\hline Waktu Pembakaran $(\mathrm{s})$ & 5000 & Diambil waktu terlama pd tungku tradisional masyarakat \\
\hline Daya Tungku $(\mathrm{kw})$ & 11,24 & \\
\hline Laju Aliran Massa Tungku $(\mathrm{g} / \mathrm{sec})$ & 1,1 & \\
\hline Laju Aliran Massa Arang $(\mathrm{g} / \mathrm{sec})$ & 0,22 & \\
\hline Laju Aliran Massa gas Volatil $(\mathrm{g} / \mathrm{sec})$ & 0,89 & \\
\hline
\end{tabular}

Untuk mendapatkan hasil pembakaran sempurna rasio udara terhadap bahan bakar (AFR) akan menjadi peranan terpenting agar semua bahan bakar habis terbakar. Pada penelitian dan perancangan ini terdapat dua aliran udara yaitu primer dan sekunder. Pada udara sekunder adalah untuk suplai pembakaran awal dengan luas udara primer $0,00424 \mathrm{~m}^{2}$ yang terletak dibawah tabung, sedangkan luas udara sekunder $0,0067 \mathrm{~m}^{2}$ yang terletak di sekeliling tabung pembakaran.

Tabel. 2. Laju udara primer dengan satuan yang berbeda

\begin{tabular}{|l|l|l|}
\hline \multicolumn{3}{|c|}{ Udara Primer } \\
\hline Laju Aliran Udara Primer (g/sec) & 0,59 & \\
\hline Laju Aliran Udara Primer (1/sec) & 0,445 & \\
\hline Laju Aliran Udara Primer (1/sec) & 2,12 & Jika oksigen di udara $21 \%$ \\
\hline Laju Aliran Udara Primer (m3/sec) & 0,00212 & \\
\hline
\end{tabular}

Tabel.3.Laju udara sekunder dengan komposisi gas volatilitas

\begin{tabular}{|l|l|l|}
\hline \multicolumn{2}{|c|}{ Udara Sekunder } & \\
\hline Laju Aliran Massa Karbon $(\mathrm{g} / \mathrm{sec})$ & 0,34 & \\
\hline Laju Aliran Massa Hidrogen $(\mathrm{g} / \mathrm{sec})$ & 0,065 & \\
\hline Laju Aliran Massa Oksigen $(\mathrm{g} / \mathrm{sec})$ & 0,48 & \\
\hline Total Aliran massa oksigen yang dibutuhkan karbon $(\mathrm{g} / \mathrm{sec})$ & 0,942 & \\
\hline Aliran udara sekunder $(\mathrm{m} 3 / \mathrm{sec})$ & 0,0034 & \\
\hline Kecepatan udara masuk lubang $(\mathrm{m} 3 / \mathrm{sec})$ & 0,5 & 0,0034 \\
\hline Laju aliran udara sekunder $(\mathrm{m} 3 / \mathrm{sec})$ & & \\
\hline
\end{tabular}

Tabel 4. Jumlah lobang udara primer dan sekunder yang dibutuhkan

\begin{tabular}{|l|c|l|}
\hline \multicolumn{3}{|c|}{ Jumlah lobang udara yang dibutuhkan } \\
\hline Luas udara primer (m2) & 0,00424 & \\
\hline Luas udara sekunder $(\mathrm{m} 2)$ & 0,0067 & \\
\hline Diameter lobang (mm) & 10 & \\
\hline Jumlah lobang udara primer (buah) & 13 & Lobang berada di bawah tabung bakar \\
\hline Jumlah lobang udara sekunder (buah) & 21 & Lobang berada di sekeliling tabung \\
\hline Keliling lingkaran ruang bakar (mm) & 2919 & \\
\hline
\end{tabular}


Selain itu untuk meningkatkan efisiensi panas agar tidak terbuang perlu dilakukan perhitungan ketebalan isolator. Yang berarti sistem ruang pembakaran harus adiabatis dan terjadi rugi kalor panas ke lingkungan.

Tabel 5. Tabel perhitungan isolator tungku pembakaran.

\begin{tabular}{|l|c|c|}
\hline \multicolumn{1}{|c|}{ Deskripsi } & $\begin{array}{c}\text { Nilai } \\
\text { Perhitungan }\end{array}$ & Keterangan \\
\hline Temperatur pusat ruang bakar $\left({ }^{0} \mathrm{C}\right)$ & 680 & \\
\hline Temperatur akhir dinding tungku $\left({ }^{0} \mathrm{C}\right)$ & 40 & \\
\hline Tinggi ruang bakar $(\mathrm{m})$ & 1,2 & \\
\hline \multicolumn{3}{|c|}{ Nilai konduktivitas thermal dan koefisien konveksi } \\
\hline Sekam padi $\left(\mathrm{W} / \mathrm{m} .{ }^{0} \mathrm{C}\right)$ & 0,036 & \\
\hline Glasswool $\left(\mathrm{W} / \mathrm{m} .{ }^{0} \mathrm{C}\right)$ & 0,04 & \\
\hline Rockwool $\left(\mathrm{W} / \mathrm{m} .{ }^{0} \mathrm{C}\right)$ & 60 & \\
\hline Udara pada $850\left(\mathrm{~W} / \mathrm{m}^{2} .{ }^{0} \mathrm{C}\right)$ & 0,053 & \\
\hline \multicolumn{3}{|c|}{ Dimensi dan jari-jari tungku } \\
\hline R1 $(\mathrm{m})$ & 0,00042 & \\
\hline R2 $(\mathrm{m})$ & 0,018 & \\
\hline R3 $(\mathrm{m})$ & 0,215 & \multirow{2}{*}{ Selisih adalah tebal isolator $=600 \mathrm{~mm}$} \\
\hline R4 $(\mathrm{m})$ & 0,815 & \\
\hline R5 $(\mathrm{m})$ & 0,24 & \\
\hline R6 $(\mathrm{m})$ & \multicolumn{2}{|c|}{} \\
\hline
\end{tabular}

Maka dari data diatas didapat bentuk tungku seperti gambar dibawah ini:

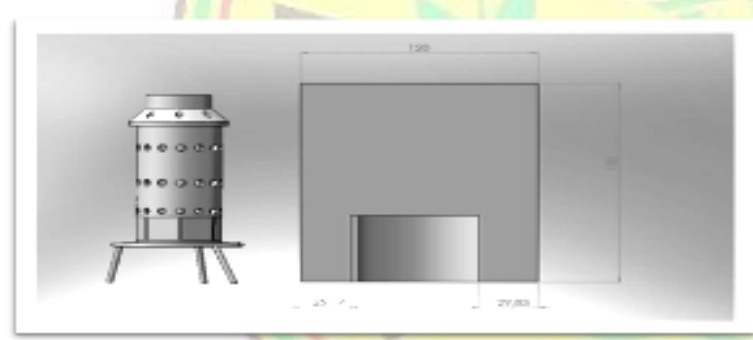

Gambar 4. Tungku hemat energi dan tabung udara primer dansekunder

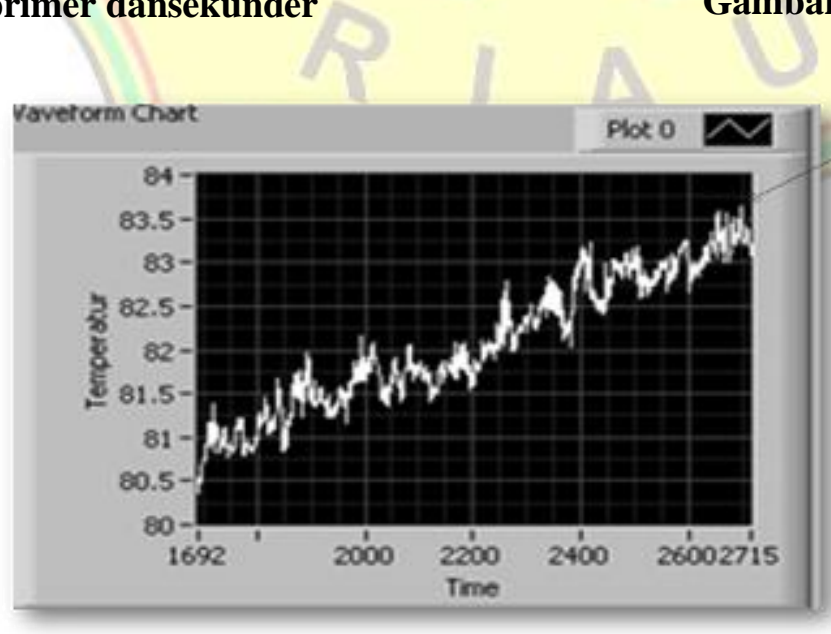

Gambar 6. Temperatur air tertinggi pada detik ke 2700

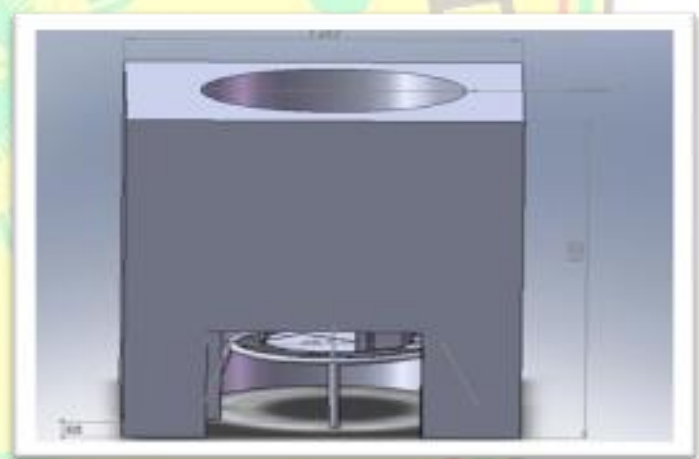

Gambar 5. Tungku dalam ruang pembakaran

Temperatur air
tertingzi pd 83,55 ${ }^{\circ}$ C pd detik ke 2700 


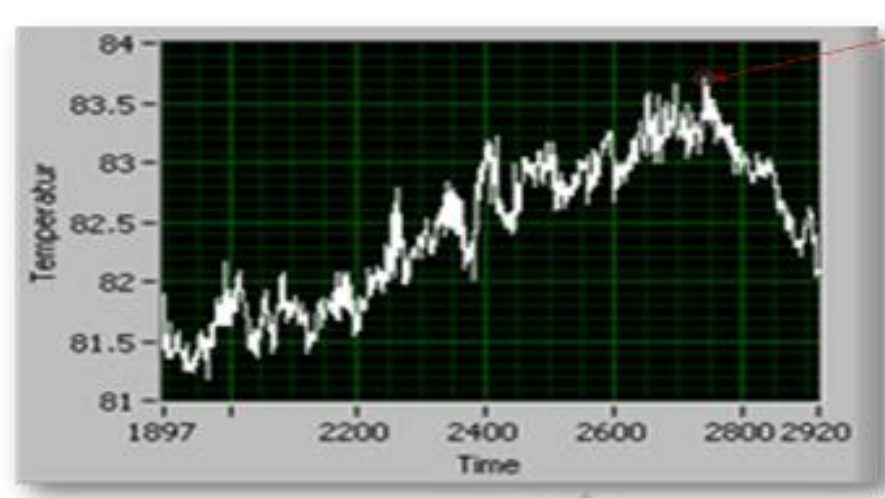

Temperatur air turun pd detik k

Gambar 7. Temperatur air turun pada detik ke 2750

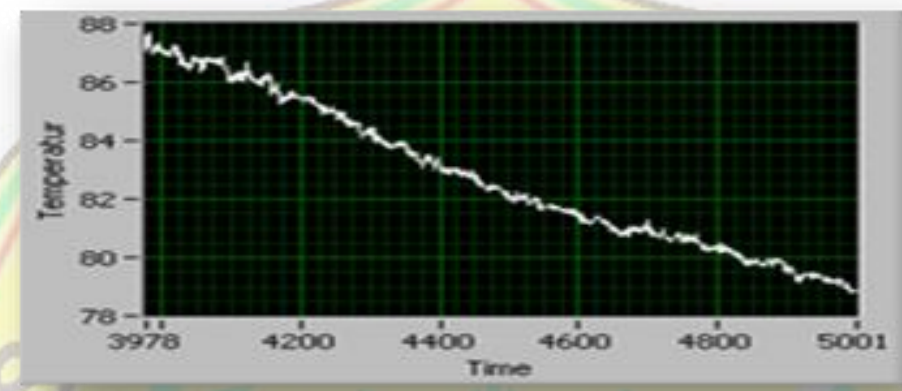

Gambar 8. Temperatur dan waktu terakhir pembakaran pada tungku tradisional

Dari ketiga grafik diatas temperatur air tertinggi yaitu $83,75{ }^{\circ} \mathrm{C}$ pada detik 2700 s, dan temeratur tersebut cenderung turun pada detik ke 2750s, hal tersebut dikarenakan bara api yang tidak tinggi dan stabil di karenakan tumpukan bahan bakar tidak mendapatkan suplai udara primer bawah. Jarak tinggi bahan bakar dengan panci adalah $75 \mathrm{~cm}$ yang mana sama dengan percobaan yang dilakukan pada tungku modfikasi. Kurangnya suplai udara pada bahan bakar kayu menyebabkan asap yang tebal seperti tampak pada gambar dibawah ini:

\section{Gambar 9. Asap dan jelaga api pembakaran pada tungku tradisional dan modifikasi}

Jelaga api yang besar selain dari suplai udara primer dari bawah bahan bakar kayu, juga diakibatkan oleh sistem semi downdraft gasifikasi yang ada dimana produksi asap dari bawah dibakar ulang oleh jelaga api yang ada pada lubang samping tabung. Pada proses ini uap yang dihasilkan hanya $0,42 \mathrm{~kg}$ lebih kecil dibandingkan dengan pembakaran tungku modifikasi sebesar $2,9 \mathrm{~kg}$. 


\section{Grafik Hasil pengukuran pada tungku modifikasi}

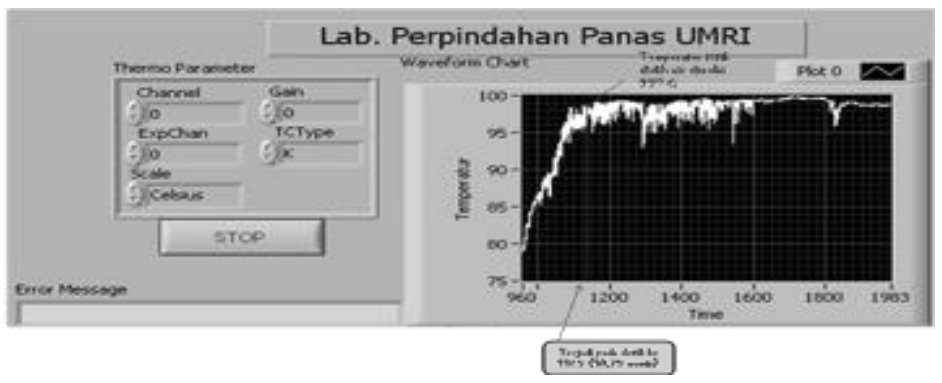

Gambar 10.Temperatur dan waktu terakhir pembakaran pada tungku tradisional

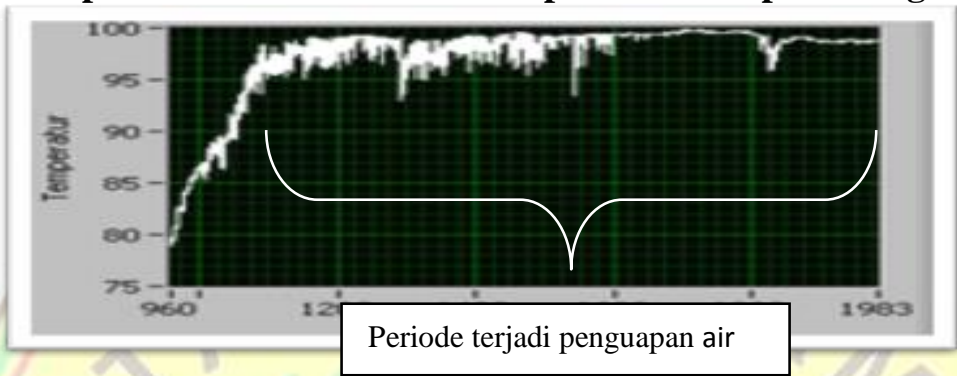

Gambar 11. Periode terjadi penguapan air

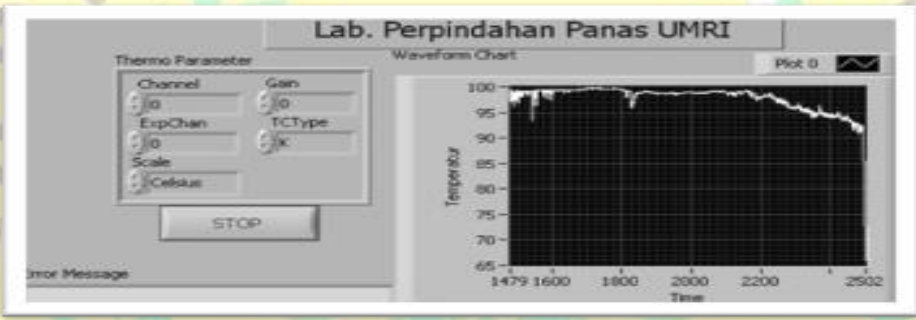

Gambar 12. Waktu terjadi penurunan air di detik 2250

Dari grafik diatas terjadi penurunan temperatur pada detik ke 2250 s. Sehingga periode penguapan yang terjadi pada tungku modifikasi dari detik 1125 ke 2250 dengan sisa berat air setelah pembakaran 3,1 kg dengan $2,9 \mathrm{~kg}$ air yang menguap. Berikut adalah tabel hasil pengujian tungku modifikasi dan tungku tradisional.

Tabel 6 Data hasil pembakaran tungku tradisional dan modifikasi

\begin{tabular}{|l|l|c|c|}
\hline No & \multicolumn{1}{|c|}{ Parameter } & Tungku tradisional & Tungku Modifikasi \\
\hline 1 & Massa bahan bakar terpakai pengujian $\mathrm{m}_{1}(\mathrm{~kg})$ & 3 & 3 \\
\hline 2 & Nilai kalor bahan bakar $\mathrm{C}_{1}(\mathrm{kkal} / \mathrm{kg})$ & 17,7 & 17,7 \\
\hline 3 & Massa air panci $\mathrm{W}_{1}(\mathrm{~kg})$ & 6 & 6 \\
\hline 4 & Berat air sisa $\mathrm{W}_{2}(\mathrm{~kg})$ & 5,58 & 3,1 \\
\hline 5 & Temperatur awal air $\mathrm{T}_{1}\left({ }^{0} \mathrm{C}\right)$ & 28 & 28 \\
\hline 6 & Temperatur air mendidih $\mathrm{T}_{2}\left({ }^{0} \mathrm{C}\right)$ & 98 & 99 \\
\hline 7 & Waktu awal penyalaan $($ menit $)$ & 0,083 & 0,083 \\
\hline 8 & Waktu awal air mendidih $($ menit $)$ & 45,83 & 18,73 \\
\hline 9 & Waktu akhir pembakaran $($ menit $)$ & 70,83 & 43,3 \\
\hline 10 & Berat bahan bakar $\left(\right.$ arang) sisa $\mathrm{m}_{2}(\mathrm{~kg})$ & 0,32 & 0,22 \\
\hline & Efisiensi thermal & $\mathbf{4 , 2} \mathbf{\%}$ & $\mathbf{1 4 , 7} \%$ \\
\hline
\end{tabular}


Dilihat dari tabel data hasil pembakaran, nilai efisiensi termal tungku modifikasi lebih besar yaitu 14,7\% dibandingkan tradisional dengan nilai 4,2 \% dengan selisih hampir seperempat dalam artian jika menggunakan bahan 100 gr pada tungku tradisional maka hanya dibutuhkan 75 gr bahan bakar pada tungku modifikasi yang berarti akumulasi panas pembakaran lebih efisien dan besar pada tungku modifikasi dengan sistem gasifikasi. Pada uji eksperimental proses pendidihan air terjadi pada menit ke 18,73 pada temperatur $99{ }^{\circ} \mathrm{C}$ untuk tungku modifikasi dan panas tertinggi $83,75{ }^{\circ} \mathrm{C}$ pada menit ke 45 untuk tungku tradisional. Sistem gasifikasi mengakibatkan pada asap tersebut ditambahkan pasokan udara/oksigen berlebih, maka asap akan terbakar dengan sempurna sehingga menghasilkan api yang jauh lebih bersih dibandingkan pembakaran langsung. Udara yang dialirkan untuk membakar asap tersebut disebut dengan secondary air. Tungku yang bekerja dengan sistem ini disebut sebagai tungku gasifikasi. Api yang jernih terjadi bila perbandingan jumlah asap dan udara untuk membakar asap memadai, umumnya pada rasio 1:3 sampai dengan 1:6.Untuk membuktikan bahwa api adalah asap yang terbakar dapat dilakukan secara sederhana. Apabila api yang menyala tiba-tiba kita padamkan secara paksa, maka akan keluar banyak sekali asap. Namun kompor gasifikasi konvensional selalu bermasalah, terutama menjelang api padam. Agar asap dapat terbakar, dibutuhkan jumlah minimum tertentu. Bila asap yang dihasilkan pada proses gasifikasi sangat banyak, maka api yang dihasilkan sangat rendah kualitasnya, nyala merah dan berjelaga. Sebaliknya, bila asap yag dihasilkan pada proses gasifikasi terlalu sedikit, maka asap tersebut tidak memenuhi jumlah minimum yang memungkinkan asap terbakar. Akibatnya, asap yang tidak terbakar lolos dari kompor dan memenuhi ruangan. Kondisi demikian umumnya terjadi pada saat menjelang api padam, terutama pada kompor gasifikasi konvensional. Untuk mengatasi masalah tersebut, dikembangkan sistem pre-heating dan pembakaran model semi gasifikasi. Sistem preheating adalah mekanisme dimana udara yang digunakan untuk proses gasifikasi (primary air) atau pembakaran asap (secondary air) mengalami pemanasan pendahuluan. Panas untuk memanaskan udara tersebut diambil dari panas radiant, yaitu panas tabung bakar yang mengarah ke samping. Harusnya panas ini terbuang. Dengan digunakannya panas radiant untuk memanaskan udara, maka terjadi proses isolasi secara tidak langsung, sehingga tabung bakar paling luar tidak menjadi sangat panas. Disamping itu, efisiensi juga akan naik, karena panas yang seharusnya terbuang ke aras samping tabung bakar, dikembalikan lagi ke tabung bakar melalui udara yang terpanaskan tadi. Proses preheating juga mencegah api padam yang mengeluarkan banyak asap, karena suhu dalam ruangan bakar menjadi lebih tinggi, akibat panas yang diumpankan kembali ke tabung bakar.

Pada kompor gasifikasi murni, terjadi pemisahan yang jelas antara ruangan gasifikasi dengan ruangan pembakaran asap. Pada model semi gasifikasi, tidak terjadi pemisahan yang jelas. Bagian ruangan tabung yang kadangkadang berfungsi sebagai ruang gasifikasi dapat juga berfungsi sebagai ruang pembakaran asap. Sistem counterflow adalah sistem yang memungkinkan udara pembakar asap (secondary air) dan asap bercampur secara turbulen. Hal ini mungkin bila arah udara untuk membakar (secondary air) asap berlawanan dengan arah asap (yang cenderung ke atas). Dengan bantuan struktur geometri kompor dengan bentuk tabung bakar menyerupai gentong (bagian bawah lebih besar dari leher di bagian atas), maka aliran udara sekunder (secondary air), akan dibelokkan ke bawah, oleh permukaan meja kompor. Akibatnya, terjadi percampuran asap dan secondary air secara turbulen, yang ujungujungnya adalah pembakaran yang lebih baik dan lebih bersih.

Sistem pembakaran secara diffused (baur) merupakan sistem pembakaran dimana api muncul dari bintik-bintik kecil sepanjang tabung bakar, seperti kompor minyak tanah. Ini berbeda dengan sistem pembakaran mengarah (concentrated), dimana api terkonsentrasi pada satu arah dari satu posisi tertentu. Sistem pembakaran diffuse sangat bagus untuk kompor 
dengan aliran udara alami, sedangkan sistem non-diffuse bagus bila ada aliran udara terpaksa, misalkan yang menggunakan blower. Air flow regulation merupakan sistem yang mengatur laju aliran udara, baik untuk gasifikasi (primary air) maupun untuk pembakaran asap (secondary air), agar api yang dihasilkan bagus. Pada kompor biomass dengan bahan bakar cangkang, hal ini ditunjukkan dengan dua panel pengatur aliran udara di bagian bawah dan bagian atas.

\section{KESIMPULAN}

Pada penelitian ini telah dilakukan perancangan, pembuatan dan pengujian terhadap tungku tradisional dan modifikasi. Pada tungku modifikasi terdapat aliran udara primer dengan 13 lobang dan sekunder 21 lobang dengan diameter $10 \mathrm{~mm}$ dengan menggunakan sistem semi downdraft gasifikasi. Diameter tungku pembakaran $35 \mathrm{~cm}$, tinggi bahan bakar kayu dengan panci $20 \mathrm{~cm}$ dan tinggi bahan bakar kayu terhadap tanah $35 \mathrm{~cm}$ dengan perlakuan yang sama terhadap tungku tradisional. Hasil yang didapatkan efisiensi termal tungku tradisional $4,2 \%$ dengan temperatur tertinggi air $86,3{ }^{\circ} \mathrm{C}$. Sedangkan pada tungku modifikasi efisiensi termal $14,7 \%$ dengan temperatur didih air $99{ }^{\circ} \mathrm{C}$ pada menit 18,73 asap hanya sedikit dibandingkan dengan pembakaran tungku tradisional.

\section{DAFTAR PUSTAKA}

M. Nurhuda Dr.Rer.nat. “ kompor biomass UB mendukung terwujudnya target penurunan emisi $26 \%$ dan kemandirian energi " Universitas Brawijaya Malang 2009. Buku: Michael J. Moran dan Howard N. Shapiro 2004, (2005), “ Termodinamika Teknik Jilid 2", Jakarta: Erlangga, 2004.

Badan Pusat Statistik Provinsi Riau " Riau dalam angka 2010" Badan Pusat Statistik 2010
Mark Bryden Dr, Dean Still, Peter Scott, Geoff Hoffa, Damon Ogle, Rob Bailis, Ken Goyer "Design principles for world burning stove" Aprovecho Research Center Shell Foundation Partnership For Clean Indoor Air.

K.Krihsna Prasad, "Some studies on open fires, shielded fires and heavy stoves" A report from the woodburning stove group departments of applied physics and mechanical engineering Eindhoven university technology, 1981

Baldwin F., 2005 Samuel Biomass stove : enginnering design VITA 1600 Wilson Boulevard, Suite 500 Arlington, Virgnia 22209 USA.

Bryden, M., Still, D., Scott, P., Hoffa, G., Ogle, D., Bailis, R., and Goyer, K., 2005. Design Principles for Wood Burning Cook Stoves, Aprovecho Research Center/Shell Foundation/Partnership for Clean Indoor Air, USEPA EPA-402-K05_004.

CDM, Simplified Project Design Documents for small scale project activities, CDM Cookstove project Kupang 1, Indonesia, 2006

Intergovernmental Panel on Climate Change, “ 2006 IPPC Guidelines for National greenhouse Inventories", Vol 2, 2006.

GREET Transportation Fuel Cycle Analysis Model, GREET 1.8b, developed by Argonne National Laboratory, Argonne, IL, released May 8, 2008.

http://www.transportation.anl.gov/software/GRE ET/index.html.

Biomass: Energi Data Book, http://cta.ornl.gov/bedb/appendix_b.shtm 1 